\title{
FAKTOR - FAKTOR YANG MEMPENGARUHI KEPUTUSAN PEMBELIAN KONSUMEN PADA USAHA BITE \& CO. CAFÉ LAMPRIT BANDA ACEH
}

\author{
Indri Nurul Mutia ${ }^{1}$, Husnaina Mailisa Safitri ${ }^{2}$ \\ ${ }^{1}$ Alumni Universitas Muhammadiyah Aceh, Banda Aceh \\ indrinurulmutia@gmail.com \\ ${ }^{2}$ Universitas Muhammadiyah Aceh, Banda Aceh \\ husnaina.mailisasafitri@yahoo.com
}

\begin{abstract}
The purpose of this research are to examine the influence of price, Word of Mouth and location towards Customers purchasing decisions at Bite \& CO. Café Banda Aceh both parcially and simultaneously. The research method by describing clearly on the research objects. The research data gathered through questionnaire list and interview. The hypothesis test uses double linear regression analysis on trust level $95 \%$ $(\alpha=0,05)$. The result of this research feasibility test model by using t-test (partial) shows that price, Word of Mouth and location significantly influence customers purcasing decisions. And using F-test (Simultaneously), it shows that price, Word of Mouth and location significantly influence customers purchasing decisions at Bite \& CO. Café Banda Aceh as well.
\end{abstract}

Keywords : Price, Word of Mouth, location, Customers Purchasing Decisions, Bite \& Co. Café 


\title{
Jurnal Bisnis dan Kajian Strategi Manajemen
}

\author{
Volume 2 Nomor 2, 2018
}

ISSN : 2614-2147

http://jurnal.utu.ac.id/jbkan

\section{PENDAHULUAN}

\section{Latar Belakang Penelitian}

Perkembangan bisnis Café di Abad ke-21 telah berkembang sangat pesat, baik dari segi kuantitas maupun kualitasnya. Ini merupakan salah satu contoh perubahan gaya hidup (life style), yang mana hal ini tidak terlepas dari pengaruh globalisasi. Makanan dan minuman merupakan kebutuhan primer manusia yang mengakibatkan bisnis kuliner memiliki nilai lebih dibanding jenis usaha lainnya. Banyaknya bisnis di bidang kuliner atau cafe yang ada di harapkan mampu meningkatkan perekonomian di Indonesia, di Aceh khususnya.

Café dan tempat makan di Banda Aceh yang telah berkembang pesat salah satunya adalah Bite \& CO. Café. Bite \& CO. Café berdiri pada Juni 2015. Berbagai jenis makanan dan minuman ala luar negeri dijual dengan harga yang terjangkau, sehingga hal ini menjadi salah satu fator keputusan pembelian konsumen pada Bite \& CO. Café. Tempat yang nyaman, lokasi yang strategis yaitu berada di pusat kota Banda Aceh, serta rasa makanan dan minuman yang enak merupakan salah satu alasan pembeli untuk datang ke tempat tersebut. Banyak warga Banda Aceh baik yang tua maupun yang muda memilih tempat ini untuk menghabiskan waktu bersantai dan berkumpul bersama keluarga. Sehingga citra positif yang ada merangsang konsumen untuk memberitahukan pengalaman mereka kepada calon konsumen lainnya yang akan berdampak pada keputusan pembelian konsumen tersebut

Proses pengambilan keputusan pembelian pada setiap orang pada dasarnya adalah sama, namun proses pengambilan keputusan tersebut akan diwarnai oleh tinggi rendahnya harga yang ditawarkan kepada konsumen, penyampaian pesan atau ide yang disampaikan (Word of Mouth) dan lokasi usaha tersebut. Secara umum keputusan pembelian adalah seleksi dari dua atau lebih pilihan alternatif. Apabila alternatif pilihan tidak ada maka tindakan yang dilakukan tanpa adanya pilihan tersebut tidak dapat dikatakan membuat keputusan. Keputusan pembelian dapat diartikan sebagai bagian dari perilaku konsumen yang bertujuan untuk menentukan proses pengembangan keputusan dalam membeli suatu barang atau jasa dimana individu terlibat secara langsung dalam mendapatkan dan mempergunakan barang atau jasa yang ditawarkan tersebut. Oleh karena itu kesimpulan terbaik individu untuk melakukan pembelian terbentuk berdasarkan kebutuhan dan keinginannya.

Namun, berdasarkan hasil observasi awal pada tanggal 13 Juli 2018 terhadap 20 konsumen, yaitu dengan membagikan angket (kuesioner) kepada konsumen Bite \& CO. Café Banda Aceh. Permasalahan yang terjadi diantaranya adalah lokasi parkir yang tidak memadai, sehingga apabila konsumen datang, sering sekali tempat parkir yang telah disediakan sudah penuh, karena lokasi Bite \& CO. Café sendiri berada di gang perumahan dan mengakibatkan minimnya tempat parkir bagi para konsumen. Berdasarkan permasalahan yang terjadi maka penulis tertarik untuk mengadakan suatu penelitian dengan judul yang berhubungan dengan Harga, Word Of Mouth dan Lokasi Terhadap Keputusan Pembelian Konsumen pada Usaha Bite \& CO. Café Lamprit Banda Aceh.

\section{Rumusan Masalah Penelitian}

Berdasarkan latar belakang penelitian di atas, maka dapat di identifikasikan masalah penelitian adalah seberapa besar pengaruh Harga, Word of Mouth dan Lokasi terhadap Keputusan Pembelian Konsumen Pada Bite \& CO. Café Banda Aceh secara parsial maupun simultan?

\section{Tujuan Penelitian}

Berdasarkan latar belakang masalah dan rumusan masalah, maka yang menjadi tujuan penelitian adalah untuk mengetahui besarnya pengaruh Harga, Word of Mouth dan Lokasi terhadap Keputusan Pembelian Konsumen Pada Bite \& CO. Café Banda Aceh secara parsial maupun simultan. 


\title{
Jurnal Bisnis dan Kajian Strategi Manajemen
}

\author{
Volume 2 Nomor 2, 2018
}

ISSN : 2614-2147

http://jurnal.utu.ac.id/jbkan

\section{Kegunaan Penelitian}

Berdasarkan rumusan masalah dan tujuan penelitian, maka kegunaan penelitian ini adalah:

a. Manfaat Teoritis

1. Sebagai wacana untuk menambah wawasan dan pengetahuan penulis mengenai Pemasaran terutama terkait dengan Harga, Word of Mouth dan Lokasi Pada Bite \& CO. Café Banda Aceh.

2. Sebagai kajian dalam melengkapi temuan-temuan empiris bagi penelitian lanjutan.

b. Manfaat Praktis

Sebagai bahan pertimbangan dan masukan kepada Bite \& CO. Café Banda Aceh mengenai Harga, Word of Mouth dan Lokasi terhadap keputusan pembelian.

\section{LANDASAN TEORITIS \\ Keputusan Pembelian}

Keputusan pembelian merupakan keputusan konsumen untuk membeli suatu produk setelah sebelumnya memikirkan tentang layak tidaknya membeli produk itu dengan mempertimbangkan informasi-informasi yang ia ketahui dengan realitas tentang produk itu setelah ia menyaksikannya. Setiap konsumen melakukan berbagai macam keputusan tentang pencarian, pembelian, penggunaan beragam produk dan jasa. Keputusan pembelian merupakan hal yang lazim dipertimbangkan konsumen dalam proses pemenuhan kebutuhan akan barang maupun jasa. Sebuah keputusan pembelian terjadi melalui proses perilaku yang terdiri dari lima tahap yaitu pengenalan masalah, pencarian informasi, evaluasi terhadap alternatif-alternatif, keputusan membeli dan kemudian hasil atau perilaku pembeli (Kotler, 2014:176).

Keputusan pembelian konsumen dipengaruhi oleh sejumlah orang memiliki keterlibatan dalam keputusan pembelian. Dan orang yang memiliki keterlibatan dalam keputusan pembelian adalah sebagai berikut :

1. Intitator adalah orang yang menyadari pertama kali adanya kebutuhan yang belum terpenuhi dan berinisiatif mengusulkan untuk membeli produk tertentu

2. Influencer adalah orang yang sering berperan sebagai pemberi pengaruh karena pandangan nasihat atau pendapatnya mempengaruhi keputusan pembelian

3. Decider adalah orang berperan sebagai pengambil keputusan dalam menentukan apakah produk jadi dibeli, produk apa yang dibeli, bagaimana cara membeli dan dimana produk itu dibeli

4. Buyer adalah orang yang melakukan pembelian aktual

5. User adalah orang yang mengonsumsi atau menggunakan produk yang dibeli.

Adapun Kotler dan Keller (2013) menyatakan indikator mengenai variabel Keputusan Pembelian Konsumen yaitu :

1. Kemantapan pada sebuah produk

Dalam melakukan pembelian, konsumen akan memilih salah satu dari beberapa alternatif yang ada. Pilihan tersebut didasarkan pada kualitas, mutu, harga yang terjangkau, dan faktorfaktor lain yang dapat memantapkan keinginan konsumen untuk membeli produk apakah produk tersebut benarbenar ingin digunakan atau dibutuhkan.

2. Kebiasaan dalam membeli produk

Kebiasaan konsumen dalam membeli produk juga berpengaruh terhadap keputusan pembelian. Konsumen merasa produk tersebut sudah terlalu melekat di benak mereka karena mereka sudah merasakan manfaat dari produk tersebut. Oleh karena itu, konsumen akan merasa tidak nyaman jika mencoba produk baru dan harus menyesuaikan diri lagi. Mereka cenderung memilih produk yang sudah biasa digunakan. 


\title{
Jurnal Bisnis dan Kajian Strategi Manajemen
}

\author{
Volume 2 Nomor 2, 2018
}

ISSN : 2614-2147

http://jurnal.utu.ac.id/jbkan

3. Faktor Lingkungan

Keadaan dimana seorang konsumen mencoba untuk melakukan keputusan pembelian setelah konsumen lain melakukan pembelian produk tersebut dilingkungannya.

4. Melakukan pembelian ulang

Kepuasan konsumen dalam menggunakan sebuah produk akan menyebabkan konsumen melakukan pembelian ulang produk tersebut. Mereka merasa produk tersebut sudah cocok dan sesuai dengan apa yang mereka inginkan dan harapkan.

\section{Harga}

Harga didefinisikan sebagai jumlah yang dibayarkan oleh pembeli. Dalam hal ini harga merupakan suatu cara bagi seorang penjual untuk membedakan penawarannya dari para pesaing. Sehingga penetapan harga dapat dipertimbangkan sebagai bagian dari fungsi deferensiasi barang dalam pemasaran. Menurut Kotler dan Armstrong (2013:151), harga merupakan sejumlah uang yang dibebankan atas suatu barang atau jasa atau jumlah dari nilai uang yang ditukar konsumen atas manfaat-manfaat karena memiliki atau menggunakan produk atau jasa tersebut. Kebijakan penetapan harga harus selaras dengan kebijakan-kebijakan penetapan harga perusahaan. Harga merupakan variabel yang dapat dikendalikan dan menentukan diterima atau tidaknya suatu produk oleh konsumen. Harga semata-mata tergantung pada kebijakan perusahaan. tetapi tentu saja dengan mempertimbangkan berbagai hal. Murah atau mahalnya suatu produk sangat relatif sifatnya.

Sedangkan Stanton (2013) menyatakan harga adalah jumlah uang (kemungkinan ditambah beberapa barang) yang dibutuhkan untuk memperoleh beberapa kombinasi sebuah produk dan pelayanan yang menyertainya. Adapun indikator harga menurut Stanton (2013) yaitu:

1. Keterjangkauan harga

Konsumen bisa menjangkau harga yang telah ditetapkan oleh perusahaan. Produk biasanya ada beberapa jenis dalam satu merk tertentu dan harganya juga berbeda dari yang termurah hingga yang termahal. Dengan harga yang ditetapkan, para konsumen dapat membeli produk yang sesuai dengan kebutuhan.

2. Potongan Harga

Potongan harga yang diberikan kepada konsumen dalam melakukan pembelian jumlah produk yang banyak.

3. Kesesuaian harga dengan kualitas produk

Harga sering dijadikan sebagai indikator kualitas bagi konsumen yang sering memilih harga yang lebih tinggi diantara dua barang, karena mereka melihat adanya perbedaan kualitas. Apabila harga tinggi, orang cenderung beranggapan bahwa kualitas produknya baik.

4. Kesesuaian harga dengan manfaat

Konsumen memutuskan membeli suatu produk jika manfaat yang dirasakan lebih besar atau sama dengan yang telah dikeluarkan untuk mendapatkannya. Jika konsumen merasakan manfaat produk lebih kecil dari uang yang dikeluarkan, maka konsumen akan beranggapan bahwa produk tersebut mahal dan konsumen akan berpikir dua kali untuk melakukan pembelian ulang.

\section{Word of Mouth}

Word of mouth adalah komunikasi dari orang ke orang antara sumber pesan dan penerima pesan dimana penerima pesan menerima pesan dengan cara tidak komersil mengenai suatu produk, pelayanan atau merk. Word of mouth merupakan bagian dari strategi promosi dalam kegiatan pemasaran yang menggunakan "orang ke orang" untuk meningkatkan kesadaran produk dan menghasilkan tingkat penjualan tertentu. Komunikasi dari mulut ke mulut (Word of Mouth) menyebar melalui jaringan bisnis, sosial dan masyarakat yang dianggap sangat berpengaruh (Hasan 


\title{
Jurnal Bisnis dan Kajian Strategi Manajemen
}

\author{
Volume 2 Nomor 2, 2018
}

ISSN : 2614-2147

http://jurnal.utu.ac.id/jbkan

2013: 230). Komunikasi dari mulut ke mulut (word of mouth) dinilai lebih meyakinkan didasari oleh seorang sumber yang menyampaikan informasi sebuah produk karena sumber tersebut puas terhadap kualitas produk tersebut. Selain itu word of mouth relatif lebih mudah dan tepat sasaran dibanding jenis promosi lain. Konsumen yang merasa puas akan menyebarkan informasi tersebut kepada konsumen lainnya, sehingga menguntungkan bagi suatu perusahaan dan juga bagi calon konsumen.

Word of Mouth merupakan sebagaian besar proses komunikasi antar konsumen. Hal ini dimaksudkan untuk saling memberikan informasi, saling memberikan pendapat tentang sesuatu produk, sehingga akan mempengaruhi keputusan pembelian konsumen (Babin, Barry J; Lee, YongKie; Kim, Eun-Fu; dan Griffin, Mitch, 2015). Indikator word of mouth sebagai berikut :

1. Kepercayaan terhadap kualitas produk. Konsumen dihadapkan oleh informasi yang didapatkan oleh konsumen lain, sehingga konsumen dapat percaya setelah mendapatkan kepuasan dengan menggunakan produk tersebut.

2. Kemauan konsumen dalam membicarakan hal-hal positif tentang kualitas produk kepada konsumen lain. Konsumen berharap mendapatkan kepuasan yang maksimal dan memiliki bahan menarik untuk dibicarakan dengan orang lain.

3. Rekomendasi produk kepada konsumen lain. Konsumen menginginkan produk yang bisa memuaskan dan memilik keunggulan di bandingkan dengan produk lainnya sehingga bisa direkomendasikan kepada orang lain.

4. Dorongan terhadap teman atau relasi untuk melakukan transaksi atas produk. Konsumen berharap mendapatkan timbal balik yang menarik pada saat mempengaruhi konsumen lain untuk membeli atau menggunakan produk tersebut.

\section{Lokasi}

Aspek lokasi dan ruang menjadi salah satu faktor penting karena keberadaannya yang terbatas dan semakin penuh oleh aktivitas manusia. Menurut Heizer \& Render (2015) lokasi adalah pendorong biaya dan pendapatan, maka lokasi seringkali memiliki kekuasanaan untuk membuat strategi bisnis perusahaan. Lokasi yang strategis sangatlah penting karena berkaitan dengan besar kecilnya biaya operasi, harga maupun kemampuan bersaing. Lokasi yang paling ideal bagi perusahaan adalah lokasi dimana biaya operasinya paling rendah atau serendah mungkin. Lokasi yang salah, akan menyebabkan biaya operasi perusahaan tinggi. Sebagai akibatnya, tidak akan mampu bersaing dan menyebabkan kerugian.

Pemilihan tempat atau lokasi memerlukan pertimbangan cermat terhadap beberapa faktor berikut (Tjiptono, 2014:159) :

a. Akses, lokasi yang dilalui atau mudah dijangkau sarana transportasi umum

b. Visibilitas yaitu lokasi yang dapat dilihat dengan jelas lebih dari jarak pandang normal

c. Lalu lintas (traffic), menyangkut kepadatan dan kemacetan

d. Tempat parkir yang luas, nyaman dan aman

e. Ekspansi, yaitu tersedia tempat yang cukup luas untuk perluasan usaha dikemudian hari

f. Lingkungan, yaitu keadaan lingkungan meliputi kebersihan dan kenyamanan lingkungan

g. Kompetitor, yaitu lokasi pesaing

h. Peraturan pemerintah, misalnya ketentuan yang melarang yang tidak baik bagi kesehatan.

Lokasi adalah keputusan yang dibuat perusahaan berkaitan dengan dimana operasi dan stafnya akan ditempatkan. Pentingnya lokasi bagi perusahaan jasa bergantung pada jenis dan derajat interkasi yang terlibat (Lupiyoadi, 2013). Indikator lokasi menurut Lupiyoadi (2013) yaitu:

1. Akses, lokasi yang dilalui atau mudah dijangkau sarana transportasi umum

2. Lalu lintas (traffic), menyangkut kepadatan dan kemacetan lalu lintas

3. Visibilitas yaitu lokasi yang dapat dilihat dengan jelas lebih dari jarak pandang normal 
4. Tempat parkir yang luas, nyaman dan aman

5. Lingkungan yaitu keadaan lingkungan meliputi kebersihan dan kenyamanan lingkungan.

\section{Kerangka Penelitian}

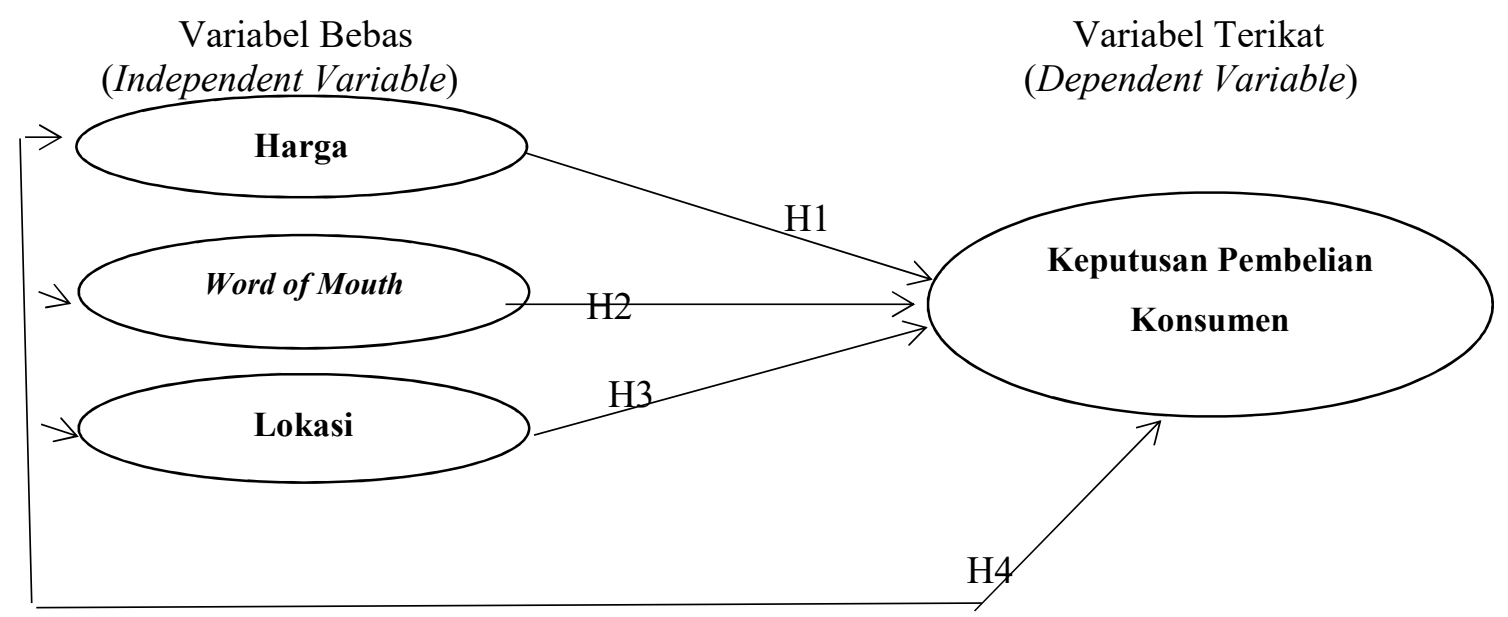

Sumber : Dikembangkan oleh Penulis berdasarkan penelitian sebelumnya, Ari Wibowo (2014)

\section{Hipotesis Penelitian}

Berdasarkan pada uraian di atas, hipotesis dalam penelitian ini adalah sebagai berikut :

H1 : Harga mempunyai pengaruh signifikan terhadap Keputusan Pembelian Konsumen Bite \& CO. Café Banda Aceh.

H2 : Word of Mouth mempunyai pengaruh signifikan terhadap Keputusan Pembelian Konsumen Pada Bite \& CO. Café Banda Aceh.

H3 : Lokasi mempunyai pengaruh signifikan terhadap Keputusan Pembelian Konsumen Bite \& CO. Café Banda Aceh.

H4 : Harga, Word of Mouth dan Lokasi mempunyai pengaruh signifikan terhadap Keputusan Pembelian Konsumen Bite \& CO. Café Banda Aceh.

\section{METODE PENELITIAN}

\section{Lokasi dan Objek Penelitian}

Penelitian ini dilaksanakan pada Usaha Bite \& CO. Café J1. Todak No. 25 Lamprit, Banda Aceh (No. Hp : 08116878 919). Objek penelitian mengenai Harga, Word of Mouth, Lokasi dan Keputusan Pembelian Konsumen.

\section{Populasi dan Sampel}

Populasi dalam penelitian ini adalah Konsumen Bite \& CO. Café. Karena jumlah pengunjung Bite \& CO. Café tidak terlalu banyak berkisar 10-15 orang/hari, memungkinkan peneliti untuk melakukan pengambilan sampel. Penarikan sampel ini berpedoman pada pendapat Arikunto (2013) yang mengatakan jika populasi kurang dari 100, lebih baik semua diambil sebagai sampel sehingg penelitian ini merupakan penelitian populasi (sensus). Jadi jumlah sampel dalam penelitian ini sebanyak 70 konsumen. Pengambilan sampel dilakukan dengan cara peneliti mendatangi konsumen Bite \& CO. Café. 


\title{
Jurnal Bisnis dan Kajian Strategi Manajemen
}

\author{
Volume 2 Nomor 2, 2018
}

ISSN : 2614-2147

http://jurnal.utu.ac.id/jbkan

\section{Peralatan Analisis Data}

Penelitian ini menggunakan jenis penelitian metode deskriptif (Descriptive research) dengan menggunakan pendekatan kuantitatif. Tehnik pengumpulan data dengan menggunakn kuisioner dan wawancara. Pengujian dan analisis data primer dilakukan dengan menggunakan perangkat SPSS Versi 22 dengan formulasi regresi linear berganda adalah sebagai berikut :

$\mathrm{Y}=\mathrm{a}+\mathrm{b}_{1} \mathrm{X}_{1}+\mathrm{b}_{2} \mathrm{X}_{2}+\mathrm{b}_{3} \mathrm{X}_{3}+\mathrm{e}$

Dimana : $\mathrm{Y}=$ Keputusan Pembelian Konsumen

a $\quad=$ Konstanta

$\mathrm{X} 1=$ Harga

$\mathrm{X} 2=$ Word of Mouth

$\mathrm{X} 3=$ Lokasi

$\mathrm{b}_{1} \ldots \mathrm{b}_{3}=$ Koefisien regresi untuk variabel $\mathrm{X}_{1}, \mathrm{X}_{2}$ dan $\mathrm{X}_{3}$

e $\quad=$ Structural error/Error Term

\section{ANALISIS HASIL PENELITIAN DAN PEMBAHASAN}

Hasil penelitian menyatakan bahwa Harga $\left(\mathrm{X}_{1}\right)$, Word of Mouth $\left(\mathrm{X}_{2}\right)$ dan Lokasi $\left(\mathrm{X}_{3}\right)$ berpengaruh terhadap Keputusan Pembelian Konsumen (Y) pada Bite \& CO. Café Banda Aceh. Model yang digunakan untuk menduga pengaruh tersebut adalah :

Tabel

Pengaruh Variabel Bebas Terhadap Keputusan Pembelian Konsumen

\begin{tabular}{|l|c|c|c|c|c|}
\hline \multicolumn{1}{|c|}{ Variabel } & B & $\begin{array}{c}\text { Std } \\
\text { Error }\end{array}$ & $\mathbf{t}_{\text {hitung }}$ & $\mathbf{t}_{\text {tabel }}$ & Sig. \\
\hline Konstanta (a) & 0,031 & 0,421 & 0,075 & 1,997 & 0,000 \\
\hline Harga (X $\mathrm{X}_{1}$ & 0,290 & 0,113 & 2,565 & 1,997 & 0,013 \\
\hline Word of Mouth $\left(\mathrm{X}_{2}\right)$ & 0,223 & 0,128 & 2,149 & 1,997 & 0,035 \\
\hline Lokasi $\left(\mathrm{X}_{3}\right)$ & 0,469 & 0,107 & 4,402 & 1,997 & 0,000 \\
\hline
\end{tabular}

Sumber: Hasil Penelitian, 2018 (Data diolah)

Berdasarkan hasil SPSS seperti terlihat tabel di atas, maka diperoleh persamaan regresi berganda sebagai berikut,

$$
\mathrm{Y}=0,031+0,290 \mathrm{X}_{1}+0,223 \mathrm{X}_{2}+0,469 \mathrm{X}_{3}
$$

Dari persamaan regresi di atas dapat diketahui hasil penelitian sebagai berikut:

1) Koefesien Regresi ( $\beta$ )

a. Dalam penelitian nilai konstanta adalah 0,031 artinya bila mana Harga $\left(\mathrm{X}_{1}\right)$, Word of Mouth $\left(\mathrm{X}_{2}\right)$ dan Lokasi $\left(\mathrm{X}_{3}\right)$ dianggap konstan, maka Keputusan Pembelian Konsumen pada Bite \& CO. Café Banda Aceh, adalah sebesar 0,031 pada satuan skala likert

b. Koefisien regresi Harga $\left(\mathrm{X}_{1}\right)$ sebesar 0,290. Artinya setiap 100\% perubahan dalam variabel Harga akan menurunkan Keputusan Pembelian Konsumen pada Bite \& CO. Café Banda Aceh sebesar 29\% dengan asumsi variabel Word of Mouth $\left(\mathrm{X}_{2}\right)$ dan Lokasi $\left(\mathrm{X}_{3}\right)$ dianggap konstan

c. Koefisien regresi Word of Mouth $\left(\mathrm{X}_{2}\right)$ sebesar 0,223. Artinya setiap $100 \%$ perubahan dalam variabel Word of Mouth secara relatif akan meningkatkan Keputusan Pembelian Konsumen pada Bite \& CO. Café Banda Aceh sebesar 22,3\% dengan asumsi variabel Harga $\left(\mathrm{X}_{1}\right)$ dan Lokasi $\left(\mathrm{X}_{3}\right)$ dianggap konstan

d. Koefisien regresi Lokasi $\left(\mathrm{X}_{3}\right)$ sebesar 0,469. Artinya setiap $100 \%$ perubahan dalam variabel Lokasi secara relatif akan meningkatkan Keputusan Pembelian Konsumen pada Bite \& CO. 


\title{
Jurnal Bisnis dan Kajian Strategi Manajemen
}

\author{
Volume 2 Nomor 2, 2018
}

ISSN : 2614-2147

http://jurnal.utu.ac.id/jbkan

Café Banda Aceh. sebesar 46,9\% dengan asumsi variabel Harga $\left(\mathrm{X}_{1}\right)$ dan Word of Mouth $\left(\mathrm{X}_{2}\right)$, dianggap konstan.

Berdasarkan hasil analisis di atas dapat diketahui bahwa dari ke tiga variabel yang diteliti ternyata variabel lokasi mempunyai pengaruh dominan dalam meningkatkan Keputusan Pembelian Konsumen pada Bite \& CO. Café Banda Aceh, karena diperoleh koefisien regresi sebesar 46,9\%.

2) Koefisien Korelasi (R) dan Determinasi

Untuk mengetahui seberapa besar kenaikan suatu linier dapat dijelaskan melalui hubungan antara veriabel-variabel (korelasi). Jika seluruh nilai dari variabel-variabel tersebut dapat memenuhi suatu persamaan dengan benar, maka dapat dikatakan terdapat korelasi yang sempurna dalam model analisis ini. Dari output SPSS dapat diketahui tingkat hubungan variabel bebas dengan variabel terikat antara lain :

Tabel 4.10

Model Summary

\begin{tabular}{|c|r|r|r|r|}
\hline Model & $\mathrm{R}$ & R Square & $\begin{array}{c}\text { Adjusted R } \\
\text { Square }\end{array}$ & $\begin{array}{c}\text { Std. Error of the } \\
\text { Estimate }\end{array}$ \\
\hline 1 &, $747^{\mathrm{a}}$ &, 558 &, 538 &, 58055 \\
\hline
\end{tabular}

a. Predictors: (Constant), Harga (X1), Word of Mouth (X2), Lokasi (X3)

Berdasarkan dari output komputer di atas maka diperoleh koefisien korelasi dalam penelitian diperoleh nilai sebesar 0,747 , dimana dengan nilai tersebut terdapat hubungan antara variabel bebas dengan variabel terikat adalah sebesar 74,7\%. Artinya Harga $\left(\mathrm{X}_{1}\right)$, Word of Mouth $\left(\mathrm{X}_{2}\right)$, dan Lokasi $\left(\mathrm{X}_{3}\right)$ mempunyai hubungan yang kuat terhadap Keputusan Pembelian Konsumen pada Bite \& CO. Café Banda Aceh.

Sementara itu koefisien determinasi yang diperoleh dengan nilai sebesar 0,223 artinya bahwa sebesar 53,8\% perubahan-perubahan dalam variabel terikat (Keputusan Pembelian Konsumen pada Bite \& CO. Café Banda Aceh) dapat dijelaskan oleh perubahan-perubahan Harga $\left(\mathrm{X}_{1}\right)$, Word of Mouth $\left(\mathrm{X}_{2}\right)$ dan Lokasi $\left(\mathrm{X}_{3}\right)$. Sedangkan selebihnya sebesar 46,2\% dijelaskan oleh faktor-faktor lain diluar tiga variabel seperti dijelaskan di atas seperti kualitas pelayanan, penanganan keluhan dan loyalitas pelanggan.

\section{Uji Parsial (Uji t)}

Untuk menguji pengaruh $\mathrm{X}_{1}, \mathrm{X}_{2}$ dan $\mathrm{X}_{3}$ terhadap $\mathrm{Y}$ pada Bite \& CO. Café Banda Aceh., digunakan uji Statistik t (uji t). Apabila nilai $\mathrm{t}_{\text {hitung }}>$ nilai $\mathrm{t}_{\text {tabel, }}$, maka $\mathrm{H}_{0}$ ditolak dan $\mathrm{Ha}$ diterima dan sebaliknya. Nilai $t_{\text {hitung }}$ dari setiap variabel independen akan dibandingkan dengan nilai $t_{\text {tabel }}$ dengan menggunakan tingkat kepercayaan (confidence interval) $95 \%$ atau $\alpha=0,05$.

1. Pengaruh Harga $\left(\mathrm{X}_{1}\right)$

Pengaruh Harga $\left(\mathrm{X}_{1}\right)$ terhadap variabel Keputusan Pembelian Konsumen (Y) secara parsial dapat dilihat pada Tabel nilai $t_{\text {hitung }}(2,565)>t_{\text {tabel }}(1,997)$, maka keputusannya adalah menolak $\mathrm{H}_{0}$ dan merima $\mathrm{H}_{\mathrm{a}}$. Dari hasil uji signifikansi secara parsial bahwa terdapat pengaruh antara Harga terhadap Keputusan Pembelian Konsumen pada Bite \& CO. Café Banda Aceh, artinya kebijakan tentang variabel Harga mempengaruhi Keputusan Pembelian Konsumen pada Bite \& CO. Café Banda Aceh.

2. Pengaruh Word of Mouth $\left(\mathrm{X}_{2}\right)$

Pengaruh Word of Mouth terhadap variabel Keputusan Kembelian Konsumen (Y) secara parsial dapat dilihat pada Tabel nilai $t_{\text {hitung }}(2,149)$ dari nilai $t_{\text {tabel }}(1,997)$. Nilai $t_{\text {hitung }}>$ nilai $t_{\text {tabel }}$, maka keputusannya adalah menolak $\mathrm{H}_{0}$ dan menerima $\mathrm{H}_{2}$. Dari hasil uji signifikansi secara parsial bahwa ada pengaruh dan signifikan antara Word of Mouth terhadap Keputusan Pembelian Konsumen pada Bite \& CO. Café Banda Aceh, artinya kebijakan tentang variabel Word of 


\title{
Jurnal Bisnis dan Kajian Strategi Manajemen
}

\author{
Volume 2 Nomor 2, 2018
}

ISSN : 2614-2147

http://jurnal.utu.ac.id/jbkan

Mouth akan mempengaruhi Keputusan Pembelian Konsumen pada Bite \& CO. Café Banda Aceh.

3. Pengaruh Lokasi $\left(\mathrm{X}_{3}\right)$

Pengaruh Lokasi terhadap variabel Keputusan Kembelian Konsumen (Y) secara parsial dapat dilihat pada Tabel nilai $t_{\text {hitung }}(4,402)$ dari nilai $t_{\text {tabel }}(1,997)$. Oleh karena $t_{\text {hitung }}(4,402)>t_{\text {tabel }}$ $(1,997)$ maka menolak $\mathrm{H}_{0}$ dan menerima $\mathrm{H}_{\mathrm{a}}$. Artinya faktor Lokasi berpengaruh signifikan terhadap Keputusan Pembelian Konsumen pada Bite \& CO. Café Banda Aceh.

\section{Uji Simultan (Uji F)}

Untuk menguji pengaruh $\mathrm{X}_{1}, \mathrm{X}_{2}$ dan $\mathrm{X}_{3}$ terhadap $\mathrm{Y}$ secara bersamaan pada Bite \& CO. Café Banda Aceh. digunakan uji Statistik F (uji F). Apabila nilai $\mathrm{F}_{\text {hitung }}>$ nilai $\mathrm{F}_{\text {tabel }}$, maka $\mathrm{H}_{\mathrm{o}}$ ditolak dan $\mathrm{H}_{\mathrm{a}}$ diterima, dan sebaliknya. Hasil Uji Simultan dapat dilihat pada tabel berikut ini :

Tabel

\begin{tabular}{|l|c|c|c|c|c|c|}
\hline \multicolumn{1}{|c|}{ Model } & $\begin{array}{c}\text { Sum of } \\
\text { Squares }\end{array}$ & Df & $\begin{array}{c}\text { Mean } \\
\text { Square }\end{array}$ & F hitung & $F_{\text {tabel }}$ & Sig. \\
\hline $\begin{array}{l}\text { Regression } \\
\text { Residual } \\
\text { Total }\end{array}$ & 28,041 & 3 & 9,347 & 27,732 & 2,746 &, $000^{\mathrm{b}}$ \\
\hline
\end{tabular}

Berdasarkan hasil perhitungan diperoleh nilai $\mathrm{F}_{\text {hitung }}$ sebesar 27,732 dengan signifikasi 0,000, sedangkan $\mathrm{F}_{\text {table }}$ pada tingkat kepercayaan (confidence interval) 95\% atau $\alpha=0,05$ adalah 2,746. Dengan membandingkan nilai $F_{\text {hitung }}$ dengan $F_{\text {table }}$, maka $F_{\text {hitung }}(27,732)$ lebih besar dari $F_{\text {table }}(2,746)$. Keputusannya adalah $\mathrm{H}_{0}$ ditolak dan $\mathrm{H}_{\mathrm{a}}$ diterima, artinya secara simultan variabel Harga $\left(\mathrm{X}_{1}\right)$, Word of Mouth $\left(\mathrm{X}_{2}\right)$ dan Lokasi $\left(\mathrm{X}_{3}\right)$ berpengaruh sangat signifikan terhadap Keputusan Pembelian Konsumen pada Bite \& CO. Café Banda Aceh.

\section{KESIMPULAN DAN SARAN \\ Kesimpulan}

Berdasarkan hasil pengujian, pengolahan dan analisis data yang telah dilakukan, maka dapat diambil kesimpulan sebagai berikut :

1. Pengujian secara parsial Harga berpengaruh signifikan terhadap Keputusan Pembelian Konsumen Pada Bite \& CO. Café Banda Aceh.

2. Pengujian secara parsial Word of Mouth berpengaruh signifikan terhadap Keputusan Pembelian Konsumen Pada Bite \& CO. Café Banda Aceh.

3. Pengujian secara parsial Lokasi berpengaruh signifikan terhadap Keputusan Pembelian Konsumen Pada Bite \& CO. Café Banda Aceh.

4. Pengujian secara simultan Harga, Word of Mouth dan Lokasi berpengaruh positif terhadap Keputusan Pembelian Konsumen Pada Bite \& CO. Café Banda Aceh.

\section{Saran}

Berdasarkan hasil penelitian maka penulis ingin menyampaikan beberapa saran ke Bite \& CO. Café sebagai berikut:

1. Memberikan harga yang ditujukan pada konsumen harus sesuai dengan besarnya manfaat atau kepuasan dalam keputusan pembelian konsumen. Dapat juga memberi potongan harga (diskon) setiap melakukan pembelian dalam jumlah banyak, sehingga dapat mempertahankan konsumen. 


\title{
Jurnal Bisnis dan Kajian Strategi Manajemen
}

\author{
Volume 2 Nomor 2, 2018
}

ISSN : 2614-2147

http://jurnal.utu.ac.id/jbkan

2. Memperhatikan konsistensi dalam hal kualitas produk, memperbanyak variasi produk, memberikan kualitas bahan yang terbaik dan dapat memberikan produk yang sesuai trend agar konsumen tetap setia mengkonsumsi produk pada Bite \& CO. Café.

3. Dapat membuka cabang Bite \& CO. Café yang lainnya dengan lokasi yang strategis dan mudah dijangkau oleh masyarakat dengan mempertahankan konsep yang sama pada Bite dan dapat dikunjungi oleh segala segmentasi.

4. Untuk penelitian selanjutnya agar tidak berfokus kepada variabel Harga, Word of Mouth dan Lokasi serta Keputusan Pembelian Konsumen saja, tapi juga meneliti variabel lainnya seperti kualitas pelayanan, penanganan keluhan dan loyalitas.

\section{REFERENSI}

Arikunto. (2013). Skala Pengukuran Likert. http://repository.unpas.ac.id/9588/9/ Bab\%20III.pdf. Diakses 11 Juli 2018.

Arikunto, Suharsimi (2013). Prosedur Penelitian Suatu Pendekatan Praktek. Jakarta : PT. Rineka Cipta.

Babin, Barry J; Lee, Yong-Kie; Kim, Eun-Fu; dan Griffin,Mitch (2015). "indikator word of mouth". http://thesis.binus.ac.id/Doc/Bab2/2012-1-00230-MN\%20Bab2001.pdf. Diakses 14 Juli 2018

Wibowo, Ari (2014). "Pengaruh Kualitas Layanan, Harga dan Lokasi Terhadap Keputusan Pembelian di D'stupid Baker Surabaya". Jurnal Ilmu \& Riset Manajemen. Sekolah Tinggi Ilmu Ekonomi Indonesia (STIESIA) Surabaya. Vol. 3 No. 12 (2014).

Heizer, Jay dan Barry Render. (2015). Operations Management (Manajemen Operasi) ed.11). http://repository.umy.ac.id/bitstream/handle/123456789/16182/F.\%20BAB \%20II.pdf?sequence=6\&isAllowed=y. Diakses 11 Juli 2018.

Jalilvand, Mohamad Reza and Neda Samiei. (2015) "The Effect of Word of Mouth on Inbound Tourists' Decision for Traveling to Islamic Destinations (The Case of Isfahan as a Tourist Destination in Iran)". Journal of Islamic Marketing, Vol. 3 No. 1.

Kotler (2014). Manajemen Pemasaran. Terjemehan oleh Benyamin Molan. Jakarta, PT Indeks.

Kotler dan Armstrong (2013). Prinsip-prinsip pemasaran. Jilid 1 dan 2. Edisi Keduabelas. Jakarta : Erlanga.

Kotler dan Armstrong (2013). Marketing Management. New Jersey : Pearson Pretice Hall, Inc.

Lupiyoadi, R. (2013). Manajemen Pemasaran Jasa Berbasis Kompetensi. Jakarta. Salemba Empat.

Malhotra, Naresh K. (2014). Riset Pemasaran : Pendekatan Terapan. Jakarta : PT. Indeks.

Nugroho, Diyos Eka Putra (2015). "Pengaruh Word of Mouth Terhadap Keputusan Pembelian Pada Cafe Roti Gempol dan Kopi Anjis Cabang Jl. Bengawan, Bandung”. e-Proceeding of Management. Fakultas Ilmu Administrasi Bisnis, Fakultas Komunikasi dan Bisnis, Universitas Telkom. Vol.2, No.1 April 2015.

Sernovitz, Andi. (2009). Word of Mouth Marketing: How Smart Companies Get People Talking. New York: Kaplan.

Stanton (2013). "Indikator Harga". http://repository.usu.ac.id/bitstream/handle/123456789/ 63729/Chapter\%20II.pdf?sequence=4\&isAllowed=y. Diakses 17 Juli 2018

Sugiyono (2016). Metode Penelitian Kuantitatif Kualitatif dan R\&D. Bandung : Alfabeta.

Zeithmal, V.A., Bitner,M.J., \& Gremler, D.D. (Purwanty A. dan Febrian A., 2015). Service Marketing. New York : McGraw-Hill/Irwin. 